\title{
Information is Power: An Interventional Study on Parents of Children with Febrile Seizures
}

\section{Bilgi Güçür: Febril Konvülsiyon Geçiren Çocukların Aileleri Üzerine Müdahaleli Bir Çalıșma}

\author{
Deniz Özalp Kızılay ${ }^{1}$ Asusinem Akyalçın Kırdök², Pelin Ertan³, Senem Ayça4, \\ Mehmet Murat Demet ${ }^{5}$, Muzaffer Polat ${ }^{4}$ \\ ${ }^{1}$ Celal Bayar University Faculty of Medicine, Department of Pediatrics, Manisa, Turkey \\ ${ }^{2}$ Atatürk Training and Research Hospital, Clinic of Psychiatry, Izmir, Turkey \\ ${ }^{3}$ Celal Bayar University Faculty of Medicine, Department of Pediatrics, Division of Pediatric Nephrology, Manisa, Turkey \\ ${ }^{4}$ Celal Bayar University Faculty of Medicine, Department of Pediatrics, Division of Pediatric Neurology, Manisa, Turkey \\ ${ }^{5}$ Celal Bayar University Faculty of Medicine, Department of Psychiatry, Manisa, Turkey
}

\begin{abstract}
Aim: Febrile seizures (FS) cause great fear and panic in the families. The majority of parents think that they may lose their child during a seizure, and feel anxious about the possibility of seizures recurring in the future. We believe that educating the families with high levels of anxiety due to FS may help to reduce the level of anxiety. In this study, we aimed to determine the needs of parents regarding FS, and the effect of education on FS on the approach and anxiety of the parents. Materials and Methods: In our study, we interviewed the parents of 113 children who suffered from FS. We conducted a survey aiming at detailed detection of knowledge, attitudes, thoughts and concerns of the families about FS, and their approaches to fever and FS. We also performed Hospital Anxiety and Depression Scale and State-Trait Anxiety Inventory to determine the levels of anxiety and depression of the parents.

Results: In this study, we found that parents were misinformed and had misbeliefs suggesting that FS damage the brain and cause epilepsy, that they are life-threatening and electroencephalography, magnetic resonance imaging and computed tomography scans of the brain are required. We also determined a significant lack of information about interventions during a seizure and thus, a high level of anxiety.

Conclusion: We concluded that parents provided with sufficient information and given psychosocial support have their anxiety levels significantly reduced, making them better in first aid practices and reducing their requests for unnecessary preventive interventions.

Keywords: Febrile seizures, parental anxiety, education program
\end{abstract}

ÖZ

Amaç: Febril konvülsiyonlar (FK)ailelerde büyük korku ve paniğe yol açar. Çoğu aile nöbet anında çocuğunu kaybedeceğini düşünür ve gelecekte nöbetlerin tekrarlaması endişesini yaşarlar. Ailelerin eğitimi ile FK'nin yarattığı endişe düzeyini azaltabileceğimize inanmaktayız. Bu çalışmada, ailelerin FK ile ilişkili intiyaçlarını tespit edip, FK hakkındaki eğitimin FK'ye yaklaşım ve ailelerin anksiyetesi üzerine etkisini belirlemeyi amaçladık.

Gereç ve Yöntemler: Çalışmamızda çocuğu FK geçiren 113 aile ile görüşüldü. Anket uygulaması ile ailelerin FK hakkındaki bilgi, düşünce, tutum ve endişelerini detaylı olarak saptamaya çalıştık. Ayrıca ailelerin depresyon ve anksiyetesini belirlemek için Hastane Anksiyete ve Depresyon Skalası ile Anksiyete Kişisel Bildiri Envanteri'ni uyguladık.

Bulgular: Bu çalışmada, ailelerin FK'nin beyine hasar verip epilepsiye yol açı̆̆ı, yaşamı tehdit eden bir hastalık olduğu, elektroensefalografi, manyetik rezonans görüntüleme ve bilgisayarlı tomografi ile değerlendirme gerektiğine dair yanlış bilgi ve inanışa sahip olduklarını gördük. Bunun yanında nöbet anında nasıl müdahale edeceklerini bilmedikleri ve bunun da yüksek anksiyeteye yol açtı̆ı̆ıı gördük.

Sonuç: Yeterli bilgi ve psikososyal destek verilen ailelerin anksiyete seviyelerinde belirgin azalma olduğunu tespit ettik. Böylece ilk yardım pratiğinde düzelme ve gereksiz önleyici müdahalede azalma beklemekteyiz. Anahtar Kelimeler: Febril konvülsiyon, aile anksiyetesi, eğitici program

\section{Address for Correspondence/Yazıșma Adresi}

Senem Ayça MD, Celal Bayar University Faculty of Medicine, Department of Pediatrics, Division of Pediatric Neurology, Manisa, Turkey

Phone: +90 5557086323 E-mail: senemkaleci85@gmail.com

Received/Geliş tarihi: 02.12.2016 Accepted/Kabul tarihi: 25.01.2017

${ }^{\circ}$ Copyright 2017 by Ege University and Ege Children's Foundation

The Journal of Pediatric Research, published by Galenos Yayınevi. 


\section{Introduction}

Febrile seizures (FS) are of a benign character but remain important and relevant because of the risk of recurrence, and progression to epileptic seizures albeit very rarely (1-3). FS are the most common seizure type in childhood, and parental anxiety and misconceptions contribute to a relevant reduction in the quality of life of children and families after a FS.

The probability of an internal or external hazard, or the perception or interpretation of a situation as hazardous by the person arouses the feeling of anxiety. Anxiety is a normal feeling that everyone experiences from time to time but sometimes it can aggravate and turn into a pathological condition. Anxiety can be experienced in different severities from a slight feeling of unease and tension up to a degree of panic. Parental concern causes overprotection, and leads to the limitation of the activities of the child, resulting in a decrease in the quality of life of both the parents and the children. FS, especially if experienced for the first time, cause fear and panic in the family. The majority of the parents think that their child may die during a seizure $(4,5)$. Especially the parents of children with recurrent FS are more troublesome, being quite apprehensive of the risk of recurrence, and they may even experience sleep disorders or other functional disorders for weeks $(6,7)$.

Previous studies have tried to obtain qualitative information by questioning the attitudes and emotional state of the parents during and after previous seizures $(5,8,9)$. It is suggested that educating the families with high levels of anxiety may be helpful in reducing the levels of anxiety.

In this study, we tested the effect of a modular education program on parental anxiety regarding febrile convulsions.

\section{Materials and Methods}

The study sample: A total of 172 children who attended the pediatric emergency department, pediatric outpatient clinic, and pediatric neurology clinic were included in the study with 113 children in the patient group and 59 children in the control group.

Selection of the patient group: Diagnosis of FS was made according to the occurrence of FS with a body temperature of $>37.8^{\circ} \mathrm{C}$ in children between 3 months and 5 years old without any defined reason such as central nervous system infection, acute electrolyte disturbances, intoxication, or a history of an afebrile or newborn seizure $(3,10)$.

Selection of the control group: The control group consisted of children who had similar characteristics with the patient group in terms of age, sex and socio-cultural level. None of the children in this group had epilepsy, FS or a chronic disease. All the children in this group were normal neurologically, and displayed normal developmental stages.

Socio-demographic and clinical data sheet: $A$ 42-question survey was conducted among the parents of the children who were included in the study with the aim of detecting the knowledge, thoughts, concerns, of the parents about fever and FS, and their attitudes and approaches towards them. A family history of FS, and educational status (less and more than 8 years) of the family were recorded.

Psychometric scales: The following psychiatric scales were used to determine the levels of anxiety and depression:

1. Hospital Anxiety and Depression Scale (HADS) which was originally developed by Zigmond and Snaith (11) and studied by Aydemir et al. (12) for the validity and reliability of the Turkish version.

2. State-Trait Anxiety Inventory (STAI) which was originally developed by Spielberger et al. (13) and translated into Turkish by Öner and LeCompte (14).

After the intervention of febrile convulsions, the families answered the questionnaires for the first time at admission to hospital. Also, the anxiety levels of the parents were determined by anxiety tests prior to education. The families received a 30-minute education program from the same pediatrician before their children were discharged. Each family was interviewed individually, not in a group.

The education program included 3 modules $(10$ minutes were allotted to each module):

Module I: (Step 1) The type of seizure (generalized tonic-clonic focal, or atonic) was watched using hometype video clips; (step 2) the seizure was classified as complex (focal, lasting more than 15 minutes, and recurrences in 24 hours or within the same febrile illness); or simple (the time elapsed between the fever and the seizure ( $1^{\text {st }}$ hour, $>1$ and $\leq 24$ hours, or $<24$ hours); and (step 3 ) the effects of FS on children were explained using printed cartons.

Module II: The proper management of the child during the episodes of fever and seizure were explained to the parents and caregivers with a power-point presentation.

Module III: The experiences of parents on previous FS issues including typical reactions of the families to FS, the etiology of the fever and FS, advice on first aid during fever and FS, treatment requirements, risk factors for recurrence, and the transformation of FS into epilepsy, prophylaxis and its potential side effects were discussed during the education program. It was explained to the families that FS are not as scary as they seem and have a benign character.

Anxiety levels of the parents were determined by anxiety tests prior to education. The survey and anxiety tests were re-conducted 4 weeks after the education to see their effects on the thoughts and approaches of the parents towards fever and FS, and on the anxiety levels of the parents.

The study was approved by the Celal Bayar University Local Ethics Committee (approval number: 50, 23.02.2011).

\section{Statistical Analysis}

Statistical Package for Social Sciences for Windows 10.0 software was used for the statistical analysis of the findings obtained in this study. After basic and descriptive statistical (frequency, mean, etc.) analysis, independent samples $t$ test was used for continuous variables, and chi-square $\left(\chi^{2}\right)$ test was used for categorical variables in the comparison between parents of children with FS and the control group. 
McNemar's test was used for categorical variables to compare the parents of children with FS before and after education.

\section{Results}

Of the patients diagnosed with FS, 52 (46\%) cases were female and 61 (54\%) cases were male. Male/female ratio was 1.17/1. Of the control group subjects, 27 (45.8\%) children were female and $32(54.2 \%)$ were male. Male/ female ratio was 1.18/1. There was no significant difference between sexes. Family history of FS was significantly higher in the patient group compared to the controls $(p=0.01)$. The education levels of the mothers and fathers of the control group were higher than those of the parents of the patients ( $p=0.005-0.004$, respectively).

As for the duration of the seizures, they lasted less than 1 minute in $25.9 \%$ of the children, $1-5$ minutes in $44.6 \%, 5-10$ minutes in $21.4 \%$, more than 10 minutes in $8.1 \%$, and more than 30 minutes in $0.9 \%$ of the children. Recurrence was observed in 39 of the cases (34.5\%). Only one seizure was experienced by $65.5 \%$ of the children, while $19.5 \%$ of them experienced two seizures, $9.7 \%$ experienced three, and $5.3 \%$ of the children experienced more than three seizures.

In the patient group, when parents were asked about their feelings on witnessing or being informed of their children's seizure, $61.9 \%$ stated fear, $20.4 \%$ said panic, $8.8 \%$ expressed sadness, $7.1 \%$ stated cool-headedness, and $1.8 \%$ claimed guilt.

The parents' level of anxiety significantly decreased after the education program $(p=0.01)$ (Table I). Calculated values for the anxiety levels of the parents in the patient group were

\begin{tabular}{|l|l|l|l|}
\hline Table I. Scores of anxiety-depression scale in febrile seizures group \\
\hline Scales & $\begin{array}{l}\text { Before } \\
\text { education }\end{array}$ & $\begin{array}{l}\text { After } \\
\text { education }\end{array}$ & $\mathbf{p}$ \\
\hline STAI state & $43.3 \pm 7.5$ & $38.7 \pm 7.1$ & $\mathbf{0 . 0 1}$ \\
\hline STAI trait & $46.7 \pm 6.1$ & $44.3 \pm 6.6$ & $\mathbf{0 . 0 1}$ \\
\hline HADS anxiety & $7.2 \pm 4.4$ & $5.5 \pm 3.8$ & $\mathbf{0 . 0 1}$ \\
\hline HADS depression & $6.6 \pm 3.9$ & $5.6 \pm 3.3$ & $\mathbf{0 . 0 1}$ \\
\hline STAI: State-Trait Anxiety Inventory, HADS: Hospital Anxiety and Depression Scale \\
\hline
\end{tabular}

$43.3 \pm 7.5$ for STAl trait, and $46.7 \pm 6.1$ for STAI continuity, $7.2 \pm 4.4$ for HADS anxiety, and 6.6 \pm 3.9 for HADS depression before education. After the education program, the values were detected as $38.7 \pm 7.1$ for STAI trait, and $44.3 \pm 6.6$ for STAI continuity, $5.5 \pm 3.8$ for HADS anxiety, and $5.6 \pm 3.3$ for HADS depression.

Before the education program, parents' perception of FS as a kind of epilepsy and electroencephalography (EEG) as a requirement was significantly more common in the patient group compared to the control group $(p=0.001$ and 0.004 , respectively), but this difference disappeared after the program. Also after the education, the number of parents who believed FS to be an age-dependent disorder turned out significantly higher in the FS group, while the number of parents who thought that brain computed tomography (CT) or magnetic resonance imaging (MRI) were required for children with FS appeared to be significantly higher in the control group ( $\mathrm{p}=0.01$ and 0.04 , respectively).

When the concerns of the families about FS were questioned, there was no significant difference between the FS group and the control group before the education program. After the education, the number of parents who believed that FS damage the brain, lead to epilepsy in the future, and are a life-threatening condition was found to be significantly lower in the patient group compared to the control group $(\mathrm{p}=0.01$, 0.02 , and 0.01 , respectively) (Table II).

The opinion that anti-epileptic drugs (this terminus refers to a long-term medication) should be prescribed for FS was significantly more common among the parents of the patients compared to those of the control group before the education program $(p=0.002)$, but this difference disappeared after education.

The intervention of putting the child on a flat surface, turning his/her head to one side, and giving rectal diazepam or midazolam (if the FS lasted for at least five minutes) were known by significantly more people in the FS group compared to the control group before education $(p=0.03$ and 0.01 , respectively). After the program, the additional intervention of cleaning the nasal and oral secretions became known by significantly more people in the patient group $(p=0.01)$.

When the interventions not recommended during FS were questioned in the FS group before and after the education program, a significant decrease was observed in

Table II. Concerns of the families about febrile seizures

\begin{tabular}{|c|c|c|c|c|c|c|c|c|c|c|}
\hline \multirow[t]{3}{*}{ Concerns of families } & \multicolumn{5}{|c|}{ Before education } & \multicolumn{5}{|c|}{ After education of FS group } \\
\hline & \multicolumn{2}{|c|}{ Group 1} & \multicolumn{2}{|c|}{ Group 2} & \multirow[t]{2}{*}{$p$} & \multicolumn{2}{|c|}{ Group 1} & \multicolumn{2}{|c|}{ Group 2} & \multirow[t]{2}{*}{$p$} \\
\hline & $\mathbf{n}$ & $\%$ & $\mathbf{n}$ & $\%$ & & $\mathbf{n}$ & $\%$ & 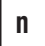 & $\%$ & \\
\hline FS damage the brain & 99 & 88.4 & 54 & 91.5 & 0.36 & 61 & 54.0 & 54 & 91.5 & 0.01 \\
\hline FS cause epilepsy in the future & 55 & 48.7 & 22 & 37.3 & 0.10 & 24 & 21.2 & 22 & 37.3 & 0.02 \\
\hline FS recur & 104 & 92.0 & 54 & 93.1 & 0.53 & 105 & 92.9 & 54 & 93.1 & 0.62 \\
\hline FS are a life-threatening condition & 99 & 87.6 & 55 & 93.2 & 0.19 & 82 & 72.6 & 55 & 93.2 & 0.01 \\
\hline
\end{tabular}


interventions such as shaking the child to wake him/her up, placing something in the mouth in order to open the jaws, giving a shower, and splashing water or cologne to the face ( $p=0.002,0.01,0.01,0.01$, respectively) (Table III).

\section{Discussion}

The appearance of a child during a FS is such a terrible sight for the family that they may think their child is dying (8). There are a number of studies on the reactions of parents during and after FS $(5,15,16)$. These reactions include physical, psychological and behavioral symptoms. FS are a potential cause for the deterioration of the quality of family life. Parents feel extreme anxiety and fear during fever, and they also think that their child is weak and vulnerable. It is important for the doctors to know about the misperceptions, anxiety, and fears of the parents. Discussion with the family has been suggested as the best medicine for FS (17). Thus, the fears and expectations of the families for medical therapy may be reduced.

In this study, the effect of a modular education program on parental anxiety and depression in febrile convulsions were investigated. The level of anxiety and depression of the parents were significantly decreased after a 4-week period with a modular education program. STAI and HADS were used to determine the levels of anxiety and depression of the parents. The calculated values for the anxiety levels of the parents in the patient group were $43.3 \pm 7.5$ for STAI trait, and $46.7 \pm 6.1$ for STAI continuity, which decreased to $38.7 \pm 7.1$ for STAI trait, and $44.3 \pm 6.6$ for STAI continuity. Hospital anxiety and depression values of the parents decreased from 7.2 \pm 4.4 for HADS anxiety, and 6.6 \pm 3.9 for HADS depression to $5.5 \pm 3.8$, and $5.6 \pm 3.3$ respectively.

Shuper et al. (18) determined that the parents' insufficient knowledge occupies an important place in parental anxiety, and Melnyk et al. (19) determined that parents need information on understanding the reactions of their children and coping with stress. In a study of Rutter and Metcalfe (9), $82 \%$ of the children had their family members nearby during the seizure, and $50 \%$ of these children had only their mothers near them. Also in this study, it was stated that families defined their first reactions as fear and panic (9).

Flury et al. (20) concluded that anxiety during the first seizure is associated with lower levels of education, and specific and repetitive education may provide a significant advantage for these families. Balslev (5) demonstrated the positive effect of having knowledge about FS on the behaviors of family members, reducing unnecessary anxiety levels. Similarly, Shuper et al. (18) also found a significant relationship between lower levels of knowledge and higher anxiety levels. Many parents stated that receiving education before FS was beneficial, especially via the posters in the waiting room and from health care workers rather than books (21).

There are some misbeliefs about FS, like causing suffocation, damaging or biting the tongue, damaging the brain, and resulting in epilepsy or death. These ideas play a key role through lack of information in the feeling of vulnerability the parents experience (17), and unnecessary fear may cause incorrect interventions (22). When asked the question whether therapy with anti-epileptic drugs should be initiated in each case of FS, $62.8 \%$ of the parents in the FS group, and $39 \%$ in the control group answered: "yes". $45.1 \%$ of the parents in the patient group who attended the education program continued to think that an anti-epileptic drug should be given, despite a significant decrease on this point. Parmar et al. (23) suggested similar results in their study. Huang et al. (24) noted that the requirement of initiating an anti-epileptic drug in every child with FS is very common.

We determined that families lack practice in first aid, have little information about the risk of recurrence of FS, and the measures to be taken for the disease. When we asked them about their first interventions during FS, the majority of the parents in the FS group said that they would put something in the child's mouth and try to open the jaws, or take the child to the shower. A study by Kayserili et al. (25), revealed that $70 \%$ of the parents directly consulted a doctor without making any intervention. Similar studies found the rates

Table III. The interventions during febrile seizures

\begin{tabular}{|c|c|c|c|c|c|}
\hline \multirow[t]{2}{*}{ The interventions } & \multicolumn{2}{|c|}{ Before education } & \multicolumn{2}{|c|}{ After education } & \multirow[t]{2}{*}{ p } \\
\hline & $\mathbf{n}$ & $\%$ & $\mathbf{n}$ & $\%$ & \\
\hline Putting the child on a flat surface, turning his/her head to one side & 29 & 25.7 & 99 & 87.6 & 0.01 \\
\hline Removing the oral and nasal secretions & 11 & 9.7 & 61 & 54.0 & 0.01 \\
\hline Giving rectal diazepam or midazolam & 14 & 12.4 & 39 & 34.5 & 0.01 \\
\hline Being calm & 19 & 16.8 & 32 & 28.3 & 0.001 \\
\hline Shaking to wake & 17 & 15 & 4 & 3.5 & 0.002 \\
\hline Placing something in mouth in order to open the chin & 37 & 32.7 & 4 & 3.5 & 0.01 \\
\hline Taking to the shower & 37 & 32.7 & 10 & 8.8 & 0.01 \\
\hline Splashing water or cologne to the face & 11 & 9.7 & 2 & 1.8 & 0.01 \\
\hline
\end{tabular}


of $36-90 \%$ for the same parameter $(5,23,26)$. In a study of Flury et al. (20), $42 \%$ of the parents said that they would try to reduce the fever, and $29 \%$ stated that they would safely lay the child on a flat surface. In contrast, $16 \%$ of the parents said they would give mouth-to-mouth resuscitation, $5 \%$ would do cardiac massage, and $12 \%$ would hit the child on the back. After the education, some of the incorrect interventions continued, $10 \%$ of the parents said that they would do cardiac massage, $18 \%$ would give mouth-to-mouth resuscitation, and $15 \%$ would try to wake up the child by shaking him/her. Nonetheless, there was a significant increase in correct applications, and $64 \%$ of the parents said that they would put the child on a flat surface, $90 \%$ stated they would take precautions against aspiration and $95 \%$ said they would give the child diazepam rectally (20).

When asked whether EEG should be performed for every child with FS, $91.2 \%$ of the parents in the FS group, and $74.1 \%$ in the control group stated that it was a necessity. In the patient group $74 \%$ and in the control group $64.4 \%$ of the parents believed brain CT or MRI to be a requirement. There was no significant difference between the groups. After the education, $77 \%$ of the parents thought that EEG was necessary, while $49.1 \%$ said brain MRI should be done. Parents' opinions on the necessity of EEG and MRI significantly changed by education, but still appeared to be supported in high rates. In a study of Huang et al. (24), it was observed that $80 \%$ of the parents thought of EEG and/or brain CT as a requirement, but the rate of the same parameter decreased to 30\% after they received education. Parents deem EEG as a requirement because it causes no side effects, it is the best method to see whether there is epileptic activity, and it provides relief for families and even for the physicians.

Seizures can be regarded shameful by the families in developing countries (27). In our study, 4 (3.5\%) families stated that they were ashamed of having a child with FS. After the education, however, only one parent insisted on his opinion. In a study of Kayserili et al. (25), 60 (49.2\%) parents were seen to be ashamed of having a child with FS. Compared to our study, this figure is very high. We believe that this is because the ratio of the participants living in villages and towns were higher in their study, and people in small social circles may influence each other more.

When we asked whether FS recur, 92\% of the parents in the FS group, and $91.5 \%$ of the parents in the control group said "yes". In a study of Huang et al. (24), when the question was asked as "Do all FS recur?," 63.9\% of the parents answered "definitely", but this rate decreased to $41.6 \%$ after the education.

\section{Study Limitations}

A randomised controlled trial comparing groups of parents educated and not educated on FS would be more optimal in assessing the impact of the study. This can be considered as a limitation of this study.

\section{Conclusion}

The presented study provides additional support to the fact that the majority of the parents have a fear of fever and misbeliefs about FS, and they significantly lack information about interventions. A three-step modular education program developed to relieve parental anxiety was found to be highly effective in families who had children with febrile convulsions. We would like to emphasize the importance of providing parents with correct and sufficient information at the emergency department despite the fact that it is a very busy environment, and inviting them to the clinical controls in order to be given detailed information.

\section{Ethics}

Ethics Committee Approval: The study was approved by the Celal Bayar University Local Ethics Committee (Approval number: 50, 23.02.2011).

Informed Consent: Consent form was filled out by all participants.

Peer-review: External and internal peer-reviewed.

\section{Authorship Contributions}

Concept: P.E., M.P., Design: M.P., P.E., Data Collection or Processing: D.Ö.K., S.A., A.A.K., Analysis or Interpretation: M.M.D., Literature Search: S.A., A.A.K., Writing: D.Ö.K.

Conflict of Interest: No conflict of interest was declared by the authors.

Financial Disclosure: The authors declared that this study received no financial support.

\section{References}

1. Stenklyft PH, Carmona M. Febril seizures. Emerg Med Clin North Am 1994;12:989-99.

2. Blumental I. What parents think of fever. Fam Pract 1998;15:513-8.

3. Hirtz D. Febrile seizures. Pediatr Rev 1997;18:5-9.

4. Bhattacharyya M, Karla V, Gulati S. Intranasal midazolam vs rectal diazepam in acute childhood seizures. Pediatr Neurol 2006;34:355-9.

5. Balslev T. Parental reactions to a child's first febrile convulsion: A follow - up investigation. Acta Pediatr Scand 1991;80:466-9.

6. Siemes H. Anfälle und Epilepsien bei Kindern und Jugendlichen. Stuttgart, Thieme Verlag, 2001:165-80.

7. Huang MC, Liu CC, Thomas K. Parenteral responses to first and recurrent febrile convulsions. Acta Neurol Scand 2002;105:293-9.

8. Baumer JH, David TJ, Valentine SJ, Roberts JE, Hughes BR. Many parents think their child is dying when having a first febrile convulsion. Dev Med Child Neurol 1981;23:462-4.

9. Rutter $\mathrm{N}$, Metcalfe DH. Febrile convulsions - What do parents do? BMJ 1978;277:1345-6.

10. Knudsen FU. Febrile convulsions: treatment and prognosis. Epilepsia 2000;41:2-9. 
11. Zigmond AS, Snaith PR. The hospital anxiety and depression scale. Acta Psychiatr Scand 1983;67:361-70.

12. Aydemir Ö, Güvenir T, Küey L, Kültür S. Hastane Anksiyete ve Depresyon Ölçeği Türkçe formunun geçerlilik ve güvenilirliği. Türk Psikiyatri Dergisi 1997;8:280-7.

13. Spielberger $C D$, Gorsuch RL, Lushene RE. Manual for the State - Trait Anxiety Inventory (self - evaluation questionnaire). Palo Alto: Consulting Psychologists Press 1970.

14. Öner N, LeCompte A. Durumluk-Sürekli Anksiyete Envanteri El Kitabı. 1. baskı. Boğaziçi Üniversitesi Yayınları, Istanbul 1983.

15. Freeman JM. Febrile seizures: A consensus of their significance, evaluation, and treatment. Pediatrics 1980;66:1009

16. Banmer JH, David TJ, Valentine SJ, Roberts JE, Hughes BR. Many parents think their child is dying when having a first febrile convulsion. Dev Med Child Neurol 1981;23:462-4.

17. Freeman JM. The best medicine for febrile seizures. N Engl J Med 1992;327:1161-3.

18. Shuper A, Gabbay $\cup$, Mimouni M. Parental anxiety in febril convulsions. Isr J Med Sci 1996;32:1282-5.

19. Melnyk BM, Alpert-Gillis LJ, Hensel PB, Coble-Beiling RC, Rubenstein JS. Helping mothers cope with a critically ill child: a pilot test of the COPE intervention. Res Nurs Health 1997;20:3-14.

20. Flury T, Aebi C, Donati F. Febrile seizures and parental anxiety: Does information help? Swiss Med Wkly 2001;131:556-60.

21. Wassmer $E$, Hanlon M. Effects of information on parental knowledge of febrile convulsions. Seizure 1999;8:421-3.

22. Crocetti M, Moghbeli N, Serwint J. Fever phobia revisited: Have parental misconceptions about fever changed in 20 years? Pediatrics 2001;107:1241-6.

23. Parmar RC, Sahu DR, Bavdekar SB. Knowledge, attitude and practices of parents of children with febrile convulsion. J Postgrad Med 2001;47:19-23.

24. Huang MC, Liu CC, Huang CC. Effects of an educational program on parents with febrile convulsive children. Pediatr Neurol 1998;18:150-5.

25. Kayserili E, Ünalp A, Apa H, e al. Parental Knowledge and Practices Regarding Febrile Convulsions in Turkish Children. Turk J Med Sci 2008;38:343-50.

26. Kürügöl NZ, Tütüncüoglu $S$, Tekgül $H$. The family attitudes towards febrile convulsions. Indian J Pediatr 1995;62:69-75.

27. Rwiza HT, Matuja WB, Kilonzo GP, et al. Knowledge, attitude, and practice toward epilepsy among rural Tanzanian residents. Epilepsia 1993;34:1017-23. 